\title{
Building Resilient Urban Communities: The Case Study of Setubal Municipality, Portugal
}

\author{
Angela Santos ${ }^{1, * \mathbb{D}}$, Nuno Sousa ${ }^{2}$, Horst Kremers ${ }^{3}$ and José Luís Bucho ${ }^{2}$ \\ 1 Centre for Geographical Studies, Institute of Geography and Spatial Planning, Universidade de Lisboa, Rua \\ Branca Edmée Marques, 1600-276 Lisboa, Portugal \\ 2 Municipal Service of Civil Protection and Firefighters of Setubal (SMPCB), Estrada de Algeruz, \\ 2910-279 Setúbal, Portugal; nuno.sousa@mun-setubal.pt (N.S.); luis.bucho@mun-setubal.pt (J.L.B.) \\ 3 CODATA-Germany, P.O. Box 2005 48, 13515 Berlin, Germany; office@horst-kremers.de \\ * Correspondence: angela.santos@campus.ul.pt; Tel.: +351-210-443-000
}

Received: 26 April 2020; Accepted: 19 June 2020; Published: 23 June 2020

\begin{abstract}
The Sendai Framework for Disaster Risk Reduction provides several guidelines that countries should follow. Still, some scientific papers discussed the limitations, difficulties, and strategies in the implementation of these guidelines. Therefore, the objective of this review is to understand what Setubal has done to cope with disasters, and the practical strategies to mitigate them. To achieve this, several methodological guidelines and Portuguese legal documents were analyzed. The results focus on the top four natural disasters that impacted the study area (landslides, earthquakes, tsunamis, and floods), and the current pandemic of COVID-19. The practical strategies implemented on the territory involve the installation of equipment such as emergency signs and electronic panels that allow the dissemination of information to the communities in real-time. Also, the collaboration with national and international scientists provided new insight to cope with disasters, by bridging the gap between law enforcement agencies, science, first responders, and the practical needs that local stakeholders must solve on the territory. Moreover, Setubal has implemented a variety of practical and innovative measures, and therefore, could be used as a model not only to other Portuguese municipalities but also to other countries.
\end{abstract}

Keywords: prevention; mitigation of risks; landslide; earthquake; tsunami; flood; pandemic; resilient communities

\section{Introduction}

The Sendai Framework for Disaster Risk Reduction [1] provides several guidelines that are divided into four main priorities: "understanding disaster risk; strengthening disaster risk governance to manage disaster risk; investing in disaster risk reduction for resilience; and enhancing disaster preparedness for effective response and to "Build Back Better" in recovery, rehabilitation and reconstruction". Following this, United Nations Office for Disaster Risk Reduction (UNDRR) has also published several practical guidelines, including case studies, $[2,3]$ that policymakers and stakeholders all over the world can implement on their territory.

Still, some scientific papers discussed the limitations, difficulties, and strategies in the implementation the UNDRR guidelines (for example, [4-6]). On the other hand, most municipalities have their own agenda in terms of validating and updating mandatory national reports to cope with natural disasters, according to their countries' legislation. In most cases, local stakeholders do not have the time or resources to focus on the development of the above guidelines. Nevertheless, to implement the UNDRR guidelines at the local level, aligned with the national strategies and legal instruments, Setubal municipality, Portugal has implemented a local strategic process based on the strategy definition 
proposed by Sousa [7], adapted from Ribeiro [8], from which derived the mental process of the ongoing strategic planning process: "Strategy is the science and art of building, disposing and employing means of conjunctive or disjunctive influence for action [9], in a given medium and time, to materialize goals set by policy, overcoming problems and exploiting opportunities". More recently, UNDRR published a new report providing further strategies and guidelines for local disaster risk reduction strategies and plans in urban areas [10]. Thus, although the UNDRR guidelines provide very important tools for disaster risk reduction, this study will also focus on the compilation of national strategies and legal instruments that are applied at the municipal level, and how these tools can be implemented on the territory.

Therefore, given the wide scope of interventions, this review aims to present and discuss the practical measures implemented at the local level to mitigate natural disasters and the current COVID-19 pandemic. To achieve this, Setubal was chosen as the case study because it has very heterogeneous land use, as presented in Figure 1, popular beaches on the west on an area with unstable cliffs, an urban area mainly characterized by old buildings, and many industries, including establishments that fall under the Seveso Directive guidelines [11,12]. Furthermore, with this review, the authors hope to contribute to more resilient urban communities to mitigate natural disasters, not only in Portugal but to other countries.

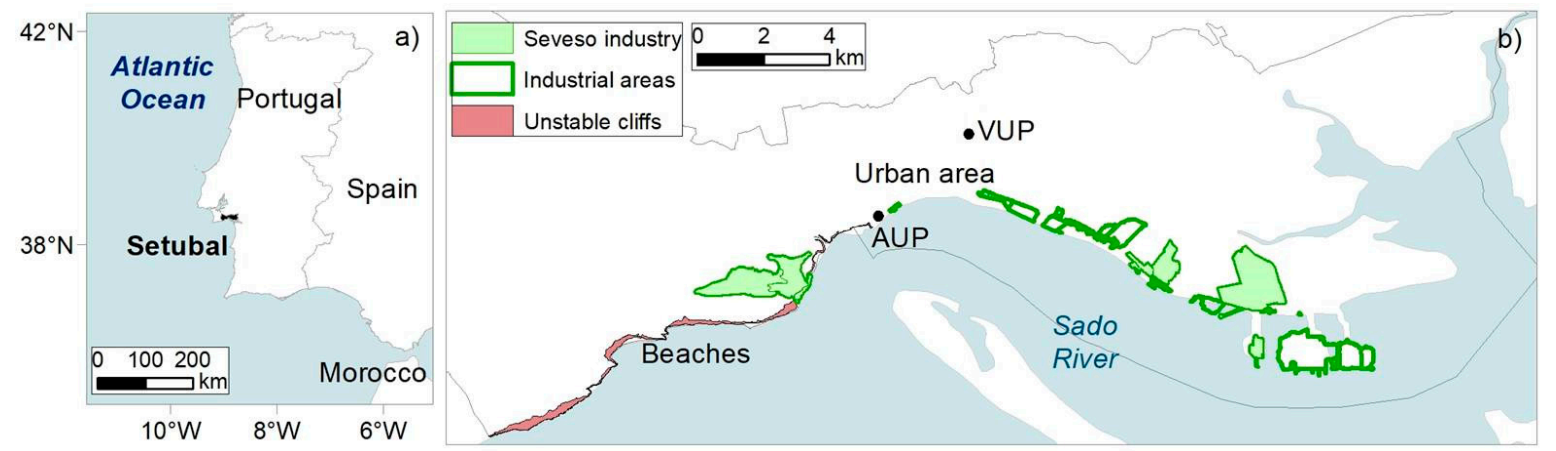

Figure 1. Coastline land use of the studied area: (a) Location of Setubal municipality; (b) Main areas including the Albarquel Urban Park (AUP) and the Varzea Urban Park (VUP). Adapted from [13,14].

\section{Methods}

The authors compiled several methodological guidelines for disaster risk reduction (DRR), at international and national levels, as presented in Figure 2. The national legal instruments are related to natural disasters and include official documents, technical reports, and guidelines for the municipal territory, according to the ruling laws in Portugal. Then, the authors analyzed what Setubal municipality had done to cope with disasters, especially the measures implemented on the territory: some technical reports were published in academia while most practical steps were created by the Setubal stakeholders themselves, which is quite innovative. This final step was conducted mainly by field survey.

Following the Sendai Framework for DRR, the National Platform for DRR (https://www.pnrrc.pt/) was created in order to provide a national response strategy to disasters and pandemics. As of January 2020, 36 Portuguese municipalities have joined the Resilient Cities Campaign, including Setubal municipality. Furthermore, the Setubal Platform (Figure 2) was created to provide local adequate response by bridging the gaps between Academia, technical reports, stakeholders' actions and the population. Moreover, these follow the "Words into Action" guidelines of UNDRR $[15,16]$ mostly by developing strategies and implementing operational measures in the areas of leveraging partnerships, adopting a multi-hazard approach and customizing approaches to fit the local context as well as sharing baseline knowledge of local disaster risk and resilience. 


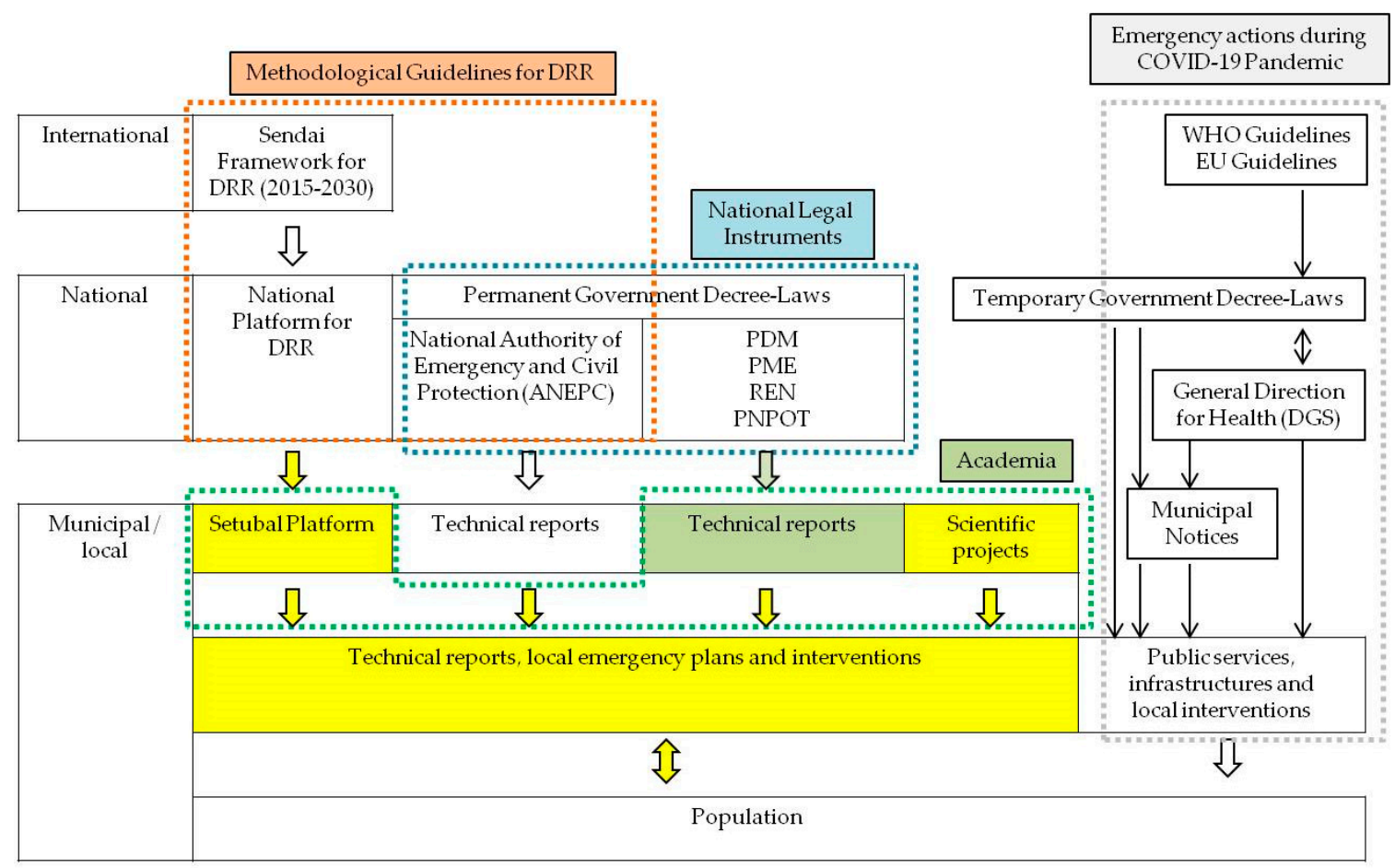

Figure 2. Schematic tools to cope with natural disasters and the current COVID-19 pandemic at international, national and the municipal/local levels. Highlighted in yellow are the strategy tools created by Setubal municipality.

Examples of the Portuguese legal instruments are the several technical reports and methodological guidelines published by the National Authority of Emergency and Civil Protection (ANEPC) over the past two decades. The latest updated report [17] suggests that the most important approach to mitigate risks is prevention (based in part on the Civil Protection Law, which contains several Decree-Laws that have been updated over time [18]). To achieve this, it is recommended that each municipality follows five general strategic objectives, summarized in Figure 3.

Another Portuguese legal instrument includes the periodic revision and validation of the Municipal Emergency Plan (PME) [19] that provides general guidelines to all the risks that could impact the territory, including natural hazards and pandemics. Since Setubal is a very heterogeneous municipality, there are specific emergency plans that have been developed: the evacuation plan of Setubal [20]; the evacuation plan to the Seveso and industrial areas (see location in Figure 1) [21]; the intervention plan at the historic center, located in the urban area (Figure 1) [22]; and the municipal plan for forest fires [23].

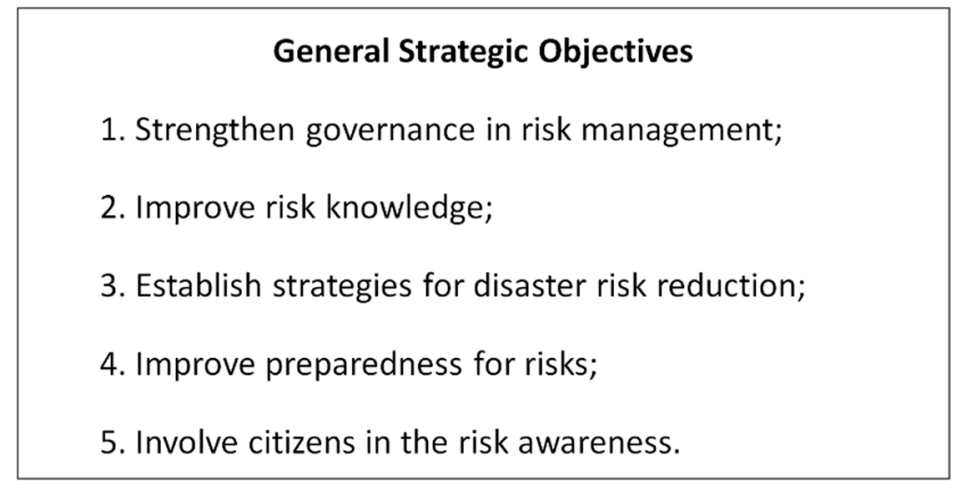

Figure 3. The five general strategic objectives recommended [17]. 
Additionally, the Municipal Plan for the Spatial Planning (PDM) [24] is also a mandatory legal an instrument, which includes the Municipal Master Plan and the Detailed Plan that provide a strategic framework for municipal development. Other legal reports related to the impact of natural disasters at Setubal have been completed by consulting academics, which in part, fulfills the second objective listed above, since these reports allow for the improvement of knowledge about risk management [25-27].

Moreover, the Municipal Directive of Civil Protection [28] defined the promotion and protection of the interests of the population, in coordination with the civil parishes that include: safety and protection of heritage, economic, cultural, environmental, and other public interests, assets, and values. The strategic directive [28] also defined the vision that "the Setubal municipality must assert itself as a national reference, as a promoter of urban safety in the field of civil protection and firefighting", will allow the improvement of its capacity for independent action.

Although biological hazards like pandemics were taken in consideration in the Municipal Emergency Plan (PME) [19], all the strategies indicated in Figure 2 were implemented as emergency and temporary actions to deal with COVID-19 pandemic (highlighted in grey).

\section{Results of the Practical Implementations and Discussion}

The compilation of natural disasters from the Portuguese legal instruments shows that Setubal municipality is exposed to more than 20 natural and technological disasters. However, this study will focus on the top four disasters which had caused most damage and fatalities in the past and that raise some concern at the present. In addition, the current COVID-19 situation in Portugal (as of May 19, 2020) is briefly analyzed. Furthermore, the practical measures applied to the territory to prevent and mitigate these disasters are also presented and discussed. Still, the situation of multi-disaster (e.g., if a large magnitude earthquake occurs during the COVID-19 pandemic) is taken into consideration on the Emergency and Contingency Plans. In fact, according to the severity of the situation, several levels among the Civil Protection Mechanism could be activated, by the municipal, district, and even national plans. Furthermore, Portugal has the military contingent that could also be activated if a critical situation/multi-disaster occurs in the country-this occurred during the 2017 forest fires.

\subsection{Landslides}

Previous reports identified 124 events in Setubal by the interpretation of orthophotomaps (2004) and field surveys [27], all occurring on the western part of the municipality, where the unstable cliffs were characterized (location in Figure 1). This area raises some concern because most beaches are located there, which are very popular during the summer, as discussed by [13]. To solve the problem, nets and walls were constructed to retain falling debris (Figure 4a). Moreover, the area has only one narrow road, leading to significant traffic (Figure $4 b, c$ ). This situation is not sustainable, but also it would be almost impossible to rescue any person in an emergency, as discussed by [13].

Thus, the Setubal municipality limited the traffic access to this area during summertime as of 2018. This measure allows the emergency services to have quick access to the beaches as well as improvement in mobility, sustainability, and environment. In order to allow residents and tourist to continue to use the beaches free buses are available during summer months (Figure $4 \mathrm{~d}$ ). The information was disseminated to the public in several ways, including YouTube videos [29]. With these approaches, general strategic objectives 1-4 listed in the Methods Section (Figure 2), may be supported. 


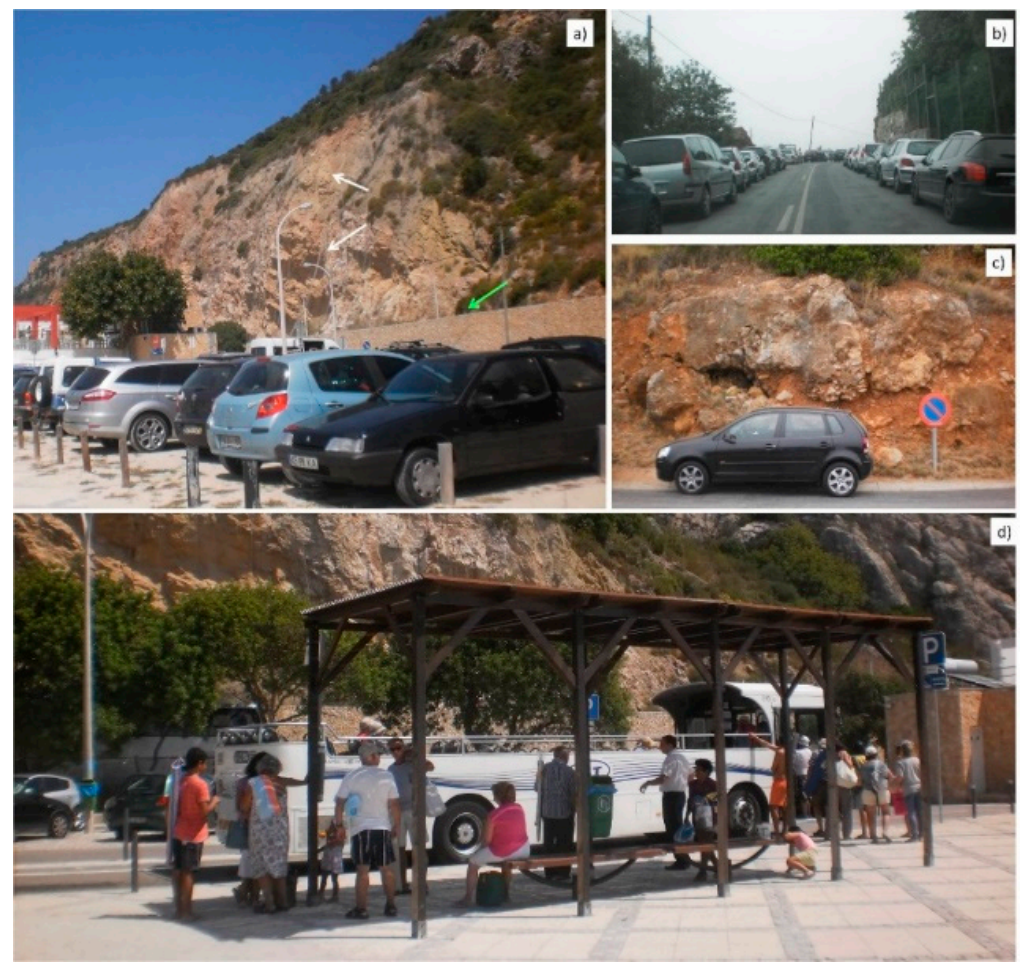

Figure 4. West part of Setubal: (a) Parking lot at a beach. White arrows: unstable cliffs protected by a net. Green arrow: reinforced wall is a secondary protection from falling debris (adapted from [13]); (b) road with parked cars; (c) people parked even on forbidden spots; (d) as of 2018, a shuttle bus was on service for free.

\subsection{Earthquakes}

According to previous studies $[13,17,30,31]$, Setubal has suffered severe damage and fatalities due to past earthquakes: 1755, 1858, 1909 and 1969, with the 1755 earthquake being the worst event. After this earthquake, a fire hit the city, showing the vulnerability of the buildings to urban fires. Following this major earthquake, the historic center of the Setubal, located in the urban area (Figure 1) has been rebuilt and even at the present day, it has many old buildings and narrow streets. Besides, according to the Census (2011) [32], 30\% of the resident population of the historic center are over 64 years old. For these reasons, if an emergency would occur in the area, especially an earthquake or fire, the emergency services would not provide fast and efficient help to residents.

Given the above reasons, the Municipal Plan of Intervention to the Historic Center [22] was implemented in 2010 to increase citizens' resilience, provide the residents with practical tools for a safe evacuation. The intervention plan [22] consists mainly of an evacuation map of the historic area (Figure 5a). Quite innovative is the implementation of a variety of equipment throughout the city center area: five Information Panels, 11 Emergency Columns, and 10 Meeting Points, as presented in Figure 5b-d. The information panel (Figure 5b) allows the dissemination of written messages in real-time. The installed equipment is a unique case in Portugal and it should serve as a guideline to other municipalities and countries, as well as in Portugal. 


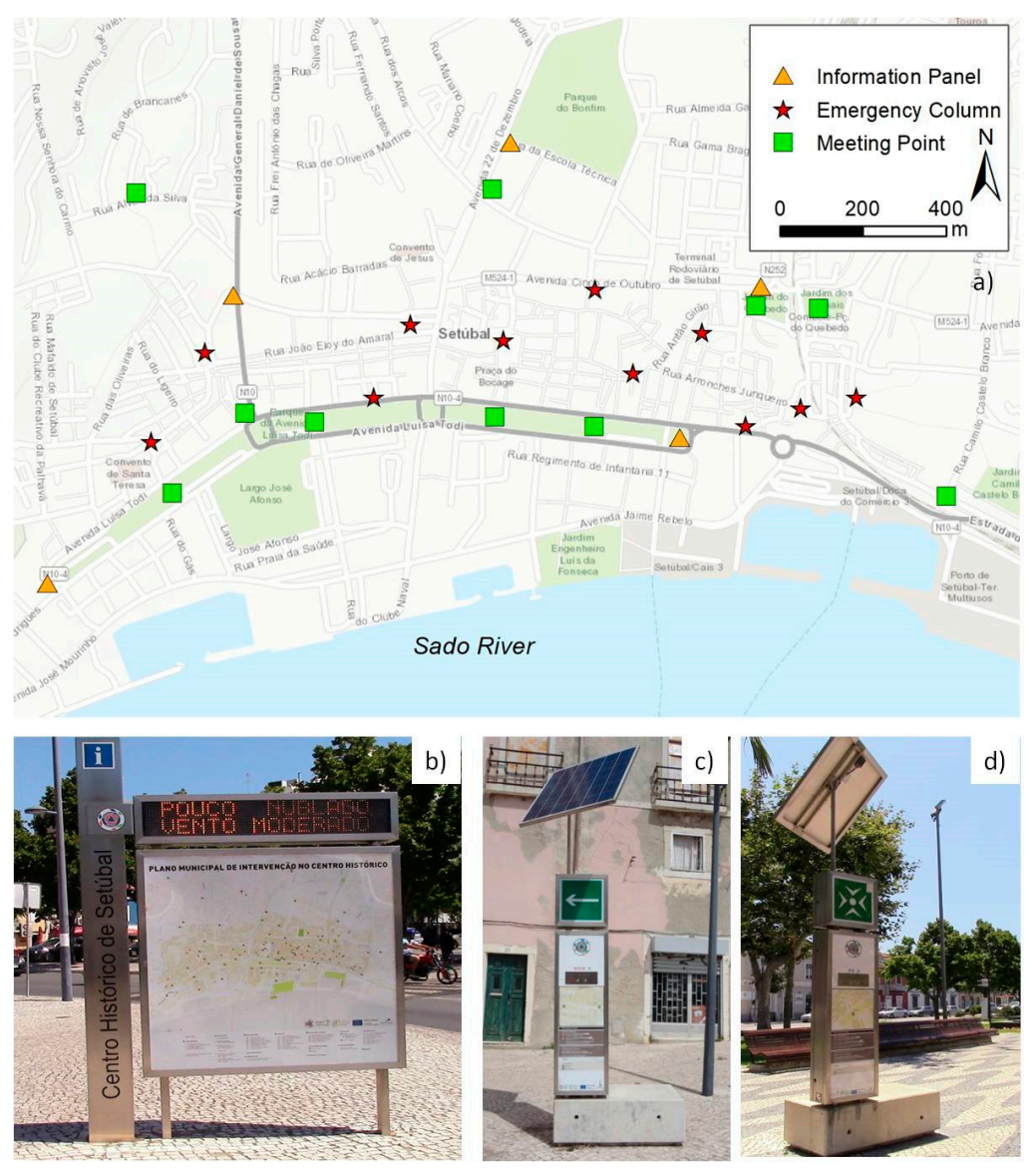

Figure 5. Municipal Plan of Intervention to the Historic Center (adapted from [22]). See location of the urban area in Figure 1: (a) Location of the installed signs; (b) information panel; (c) emergency column; (d) meeting point.

In addition, to promote the earthquake risk awareness and information among the citizens, regular citizens' assemblies on risk awareness and self-protection measures have been organized. An example was the "Bocage 2013" directed to about 800 students. Firstly, the students were briefed about earthquakes, and then the school community (teachers, students, and auxiliary staff) carried out an evacuation exercise, considering an earthquake scenario. Moreover, several temporary exhibitions have been also organized. With these approaches, strategic objectives 1, 2, 4 and 5 listed in the Methods Section (Figure 3), might be completed, at least partially. Nevertheless, information and education activities with citizens should continue. Also, regarding the strategies for earthquake risk reduction, it would involve mostly the reinforcement of the structures. This approach has not been fully implemented and constitutes a severe limitation, especially with old buildings with construction dates before the 1960s.

\subsection{Tsunamis}

Although several technical reports indicate Setubal is vulnerable to tsunamis (especially those triggered by the 1755 and 1969 earthquakes), many details have been unknown. On the other hand, the national tsunami warning system is not operational yet. Therefore, the Setubal municipality took several steps to create its own local tsunami warning system: a collaboration with the scientific project Schema allowed the installation of experimental equipment: in April 2011, a Tsunami Alerting Device (TAD) (Figure 6a) was set up in Albarquel Urban Park (location in Figure 1), with the collaboration of the Joint Research Center (European Commission) [33,34]. The device is connected to a tide gauge station, which belongs to the International Oceanographic Commission network allowing the data 
to be online [35]. The device allows for a local tsunami alerting system since it is equipped with written messages, a siren, and loudspeakers, and as of January 2020, it remains unique and innovative in Portugal.
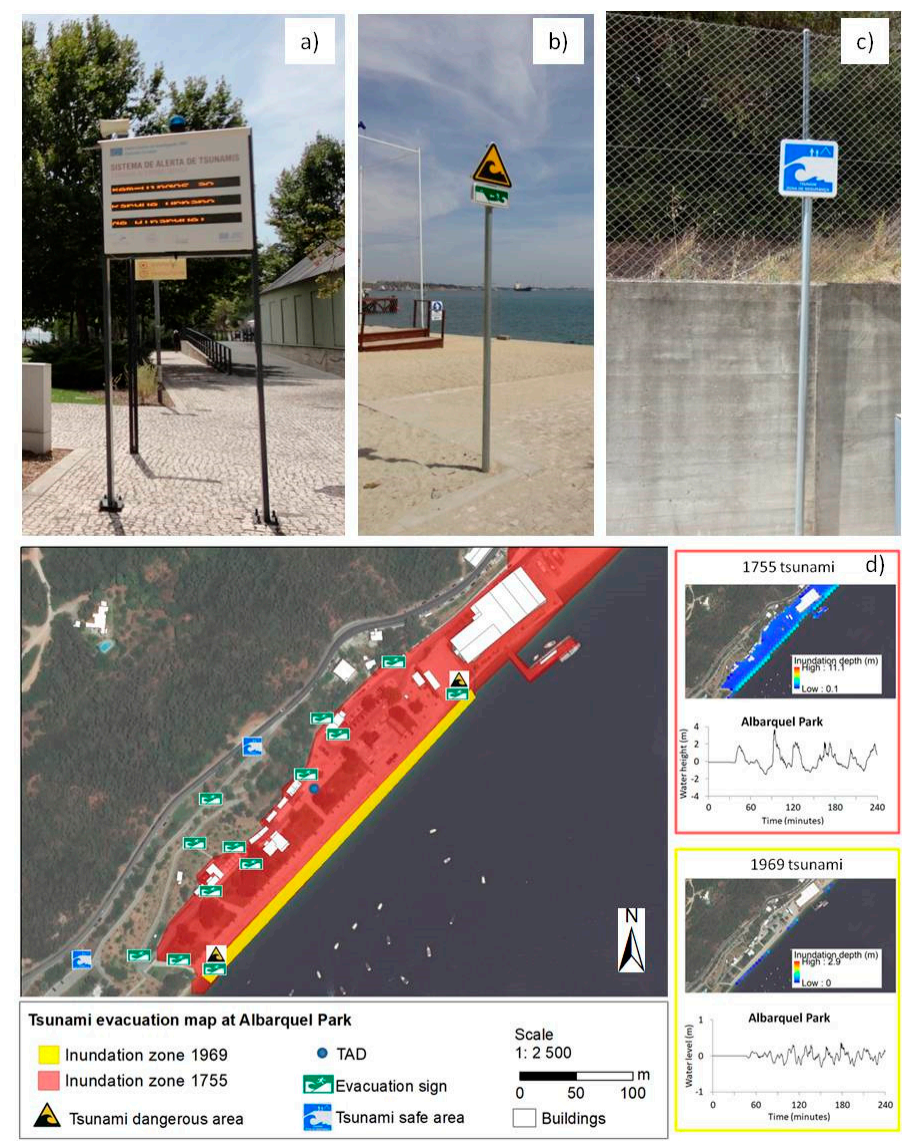

Figure 6. Installed equipment at the Albarquel Urban Park (AUP, see location in Figure 1) and evacuation map: (a) Tsunami Alerting Device (TAD); (b) signs of tsunami dangerous area and evacuation; (c) sign of tsunami safe area; (d) tsunami evacuation map at AUP (adapted from [13]).

More recently, tsunami mitigation and awareness strategies were implemented. In collaboration with a scientific team [36], the use of the tsunami numerical modeling allowed a more detailed understanding of the 1969 and 1755 tsunamis on the Setubal coastline [13], showing the municipality would be hit within 30-40 min an earthquake. In addition, the tsunami evacuation map was produced (Figure 6). What is innovative is the installation of several evacuation signs at the Albarquel Urban Park (Figure 6b,c).

Furthermore, before the 50-year anniversary of the 1969 earthquake and tsunami, during February 2019 , there were several activities to involve the citizens in earthquake and tsunami risk awareness, including a seminar, temporary exhibition, a YouTube video [37] and a TV program [38]. Therefore, with these approaches, all five strategic objectives listed in the Methods section (Figure 3) are supported, at least concerning the Albarquel Urban Park. It is still necessary to continue the educational activities with citizens and implement the tsunami evacuation maps on the Setubal municipality coastline.

\subsection{Floods}

Previous reports show the Setubal urban area (location in Figure 1) is prone to urban floods, usually within a period of fewer than 6 hours [25,27]). As a result, the Varzea Urban Park was created as a retention basin for floods. As shown in Figure 7, it has several artificial lagoons to retain, control and drain the water. The construction of the park is not yet completed, but the first phase showed it to 
be very useful to mitigate urban floods after the Elsa and Fabien storms that occurred December 16-21, 2019. The concepts of Flood Resilience Measurement for Communities (FRMC) [39] offer the structured means and can be recommended for further action.



Figure 7. One of the artificial lagoons of the Varzea Urban Park (VUP) (location in Figure 1).

According to the emergency records of Setubal Civil Protection of that period, there were 73 incidents related to falling trees, 37 related to falling structures, 35 related to flood due to intense precipitation, six incidents related to the supply of electricity and one related to the supply of gas. Thus, although flood is still a major hazard at the Setubal urban area, during the December 2019 storms the wind caused more damages than the inundations.

\subsection{Pandemics-COVID-19 Current Situation}

Portugal was following the international development of the COVID-19 outbreak as it propagated in China, then to the "Princess" Cruise Ship anchored in Japan, as well as Italy, France and Spain. The virus propagation allowed Portugal (at national and municipal levels) to have some time to be prepared since the first infected cases in the country were reported on March 2, 2020. Still, the first prevention actions to control the virus propagation were taken by the Universities of Lisbon and Coimbra that suspended all academic activities from March 9, 2020, including classes, university facilities (cafeterias and bars, university museums, libraries, gardens and all sports); classes and meetings continued to function by videoconference and by using online services and platforms, while staff were encouraged to work at home. This was the first mitigation strategy applied in the Portuguese territory. Then, the Portuguese Government took the first actions on March 12, 2020 [40] followed by other measures (published on March 16, 17, 19, 20, and 26; on April 1, 2, 9, 17, 23 and 30; on May 2, 12 and 15). The first phase of the national easing of lockdown was initiated on May 3, 2020 and the second on May 18, 2020. The second phase will be active till May 31, 2020. All these Decree-Laws were updated and adapted according to the daily data evolution provided by the General Direction of Health (DGS) [41,42].

At the national level, as of May 19, 2020 [41,42], there were 29,432 confirmed infected cases in Portugal, with 629 people admitted in hospitals, and 101 on the intensive care units; 266,720 people tested negative (while 2349 were waiting for the laboratory results), 6431 recuperated, and 1247 dead (of which 838 people were over 80 years old that correspond to about $67 \%$ of the fatalities).

At the local level, the Setubal municipality was the first municipality to activate the Municipal Commission for Civil Protection (on March 9, 2020) [43]. Then, the Municipal Emergency Plan (PME) [19] was activated following the first Alert Situation that has been declared at the national level on March 12, 2020 [40]. Under all the above national and municipal guidelines, Setubal stakeholders implemented several actions on the territory to protect and support the local populations, among them [43,44]: public communication, support to economic activities, social support to the most 
vulnerable population, support to the first responders, logistic food supplies, support of meals to underprivileged elementary school children and to the children of first responders, disinfection of public spaces, support of activities by the civil society (including the production of masks and boots by a group of seamstresses), restriction to public circulation, and supporting the Setubal Hospital in collaboration with neighbor municipalities.

Therefore, all these strategies were important to mitigate the COVID-19 impact in the country and to keep outbreaks under control, as presented in Figure 8. As of May 19, 2020 [41,42,45] there were only 80 confirmed infected cases in Setubal (Figure 8a), corresponding the 0.69 number of cases for each 1000 inhabitants (total resident population is 116044), which is one of the lowest rates in the mainland of Portugal, as shown in Figure 8b, as well as among the large cities in the country (population of more than 100,000 people). Currently, the COVID-19 pandemic is still ongoing with complex interactions, due to a combination of several factors like physical, human, economic, social, and geographic conditions. However, the high awareness of disasters is for sure an important key to mitigate the impact. The first cases of COVID-19 in Setubal were reported on March 24, 2020, with 7 infected people. As listed above, a variety of measures were taken at national and local levels. Moreover, authors were able to compile some statistical data related to activities carried out on Setubal: as of May 19, 2020, there were a total of 308 emergency meetings involving Setubal stakeholders; 229 baskets of essentials were delivered to the population; 8430 home support (delivery of groceries and medicine) and meals; 81 visits to several facilities, including 54 visits to nursing homes, supported by social services and health authorities; and accommodation to first responders (a total of 25 until April 5, decreasing to zero since May 15).
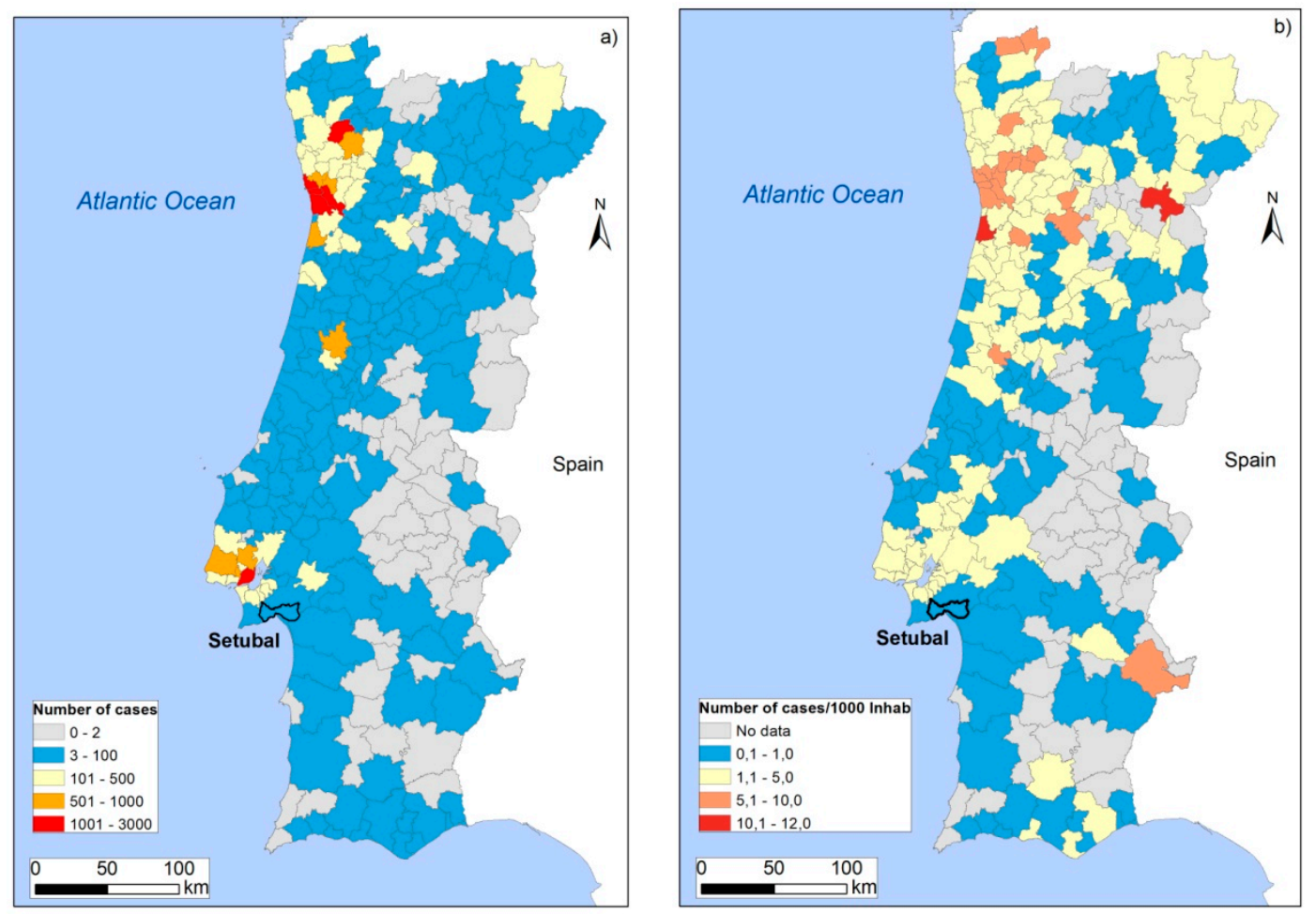

Figure 8. Geographic distribution of infected cases due to COVID-19 in Portugal mainland on May 19, 2020: (a) Number of infected cases on each municipality; (b) Number of infected cases per 1000 inhabitants on each municipality. (Data compiled from $[41,42,45]$. When less than three cases were reported, data are not shown). 


\section{Conclusions}

In this review, the authors compiled the legal instruments for the municipal territory. It was found that Portugal has many tools and guidelines (all in Portuguese) to identify and characterize natural disasters, and therefore the diagnosis of disasters is in general well documented, at least at the national level. Besides, prevention is the most important approach to mitigate risks in Portugal, which can be generalized to all countries.

The results also show that the Setubal municipality is exposed to more than 20 natural and technological disasters, but this review focused only on the top four: landslides, earthquakes, tsunamis, and floods. In addition, the ongoing COVID-19 pandemic situation was also analyzed. The practical strategies implemented on the territory involve the installation of equipment such as emergency signs and electronic panels that allow the dissemination of information to the communities in real time. Other measures involve banning traffic on those narrow streets that have a special risk concerning rescue service access and the construction of artificial lagoons. This example convincingly indicates the effectiveness of 3D urban model applications [46]. Moreover, the collaboration with national and international scientists and researchers also provided new insight to cope with disasters, by bridging the gap between law enforcement agencies, science and first responders, and the practical needs that local stakeholders need to solve on the territory. A structured approach to policies and strategies to prevent and reduce disaster risks and manage residual risks with preparedness, response and recovery activities [45-47] can assist in addressing the different needs of actor groups, respectively social subareas and domains [48-50]. In follow-up phases, the current projects and practices can be augmented to identify features for a common understanding and framework of risk, security and resilience $[47,51]$. In addition, the dissemination of information to the community is made through social media and technological channels, such as videos on YouTube.

In summary, Setubal has implemented a variety of innovative practical measures that could be used as a model, not only to other Portuguese municipalities, but also to urban areas in other countries. Moreover, the recent COVID-19 pandemic showed that all the practical measures and local experience were effective to help control the propagation of the virus in the population and to mitigate its impact.

Author Contributions: Conceptualization, A.S. and H.K.; methodology, A.S.; field work, A.S., N.S. and J.L.B.; maps: A.S.; writing-original draft preparation, A.S. and N.S.; writing-review and editing, all authors. All authors have read and agreed to the published version of the manuscript.

Funding: This research was funded by the FCT-Fundação para a Ciência e Tecnologia (Foundation of Science and Technology), UIDB/00295/2020 + UIDP/00295/2020.

Conflicts of Interest: The authors declare no conflicts of interest.

\section{References}

1. United Nations International Strategy for Disaster Reduction UNISDR. Sendai Framework for Disaster Risk Reduction 2015-2030; UNISDR: Geneva, Switzerland, 2015; p. 32.

2. Aitsi-Selmi, A.; Blanchard, K.; Al-Khudhairy, D.; Ammann, W.; Basabe, P.; Johnston, D.; Ogallo, L.; Onishi, T.; Renn, O.; Revi, A.; et al. Science Is Used for Disaster Risk Reduction; UNISDR STAG 2015 Report. UNISDR: Geneva, Switzerland, 2015; p. 46. Available online: http://preventionweb.net/go/42848 (accessed on 23 January 2020).

3. United Nations International Strategy for Disaster Reduction UNISDR. Words into Action Guidelines-National Disaster Risk Assessment_-Governance System, Methodologies, and Use of Results; UNISDR: Geneva, Switzerland, 2017; p. 303.

4. Poterie, A.T.; Baudoin, M.-A. From Yokohama to Sendai: Approaches to Participation in International Disaster Risk Reduction Frameworks. Int. J. Disaster Risk Sci. 2015. [CrossRef]

5. Aitsi-Selmi, A.; Murray, V.; Wannous, C.; Dickinson, C.; Johnston, D.; Kawasaki, A.; Stevance, A.-S.; Yeung, T. Reflections on a Science and Technology Agenda for 21st Century Disaster Risk Reduction. Int. J. Disaster Risk Sci. 2016. [CrossRef] 
6. Kremers, H.; Challenges in Operational Risk Information Management. Strategy Report. 2019. Available online: http://rimma.org/StratRep2019.pdf (accessed on 23 January 2020).

7. Sousa, N. The Civil Planning of Emergency in the New Paradigm of Safety. Master's Thesis, Universidade de Lisboa, Lisboa, Portuguese, 2016. Available online: https:/www.repository.utl.pt/handle/10400.5/11567 (accessed on 23 January 2020).

8. Ribeiro, A.S. The Essencial of the Strategic Process; Almedina: Coimbra, Portugal, 2010; p. 256. (In Portuguese)

9. Gray, C.; Murray, W. Strategy and History-Essays on Theory and Practice; Routledge: New York, NY, USA, 2006; p. 249.

10. United Nations Office for Disaster Risk Reduction UNDRR. Global Assessment Report. 2019. Available online: https://gar.undrr.org/sites/default/files/reports/2019-05/full_gar_report.pdf\#page=385 (accessed on 6 April 2020).

11. European Commission. Seveso Directive. 2019. Available online: https://ec.europa.eu/environment/seveso/ legislation.htm (accessed on 23 January 2020).

12. Caramelo, A.; Cornaglia, G.; Bucho, J.; Macedo, M.; Isabel, S.; Pires, P.; Sacadura, P. Risk. Chart of the Mitrena Peninsula National; Authority of Civil Protection and the SMPCB: Carnaxide, Portugal, 2011; p. 94. (In Portuguese)

13. Santos, A.; Fonseca, N.; Queirós, M.; Zêzere, J.L.; Bucho, J.L. Implementation of Tsunami Evacuation Maps at Setubal Municipality, Portugal. Geosciences 2017, 7, 116. [CrossRef]

14. Aleluia, A. Cartografia Digital do Concelho de Setúbal à Escala 1:10 000; Departamento de Urbanismo, Gabinete de Sistemas de Informação Geográfica, Câmara Municipal de Setúbal: Setúbal, Portugal, 2011.

15. United Nations Office for Disaster Risk Reduction UNDRR. Words into Action: Developing national Disaster Risk Reduction Strategies; UNISDR: Geneva, Switzerland, 2019; p. 45. Available online: https://reliefweb.int/ sites/reliefweb.int/files/resources/65095_wianationaldrrstrategies10052019_0.pdf (accessed on 23 May 2020).

16. United Nations Office for Disaster Risk Reduction UNDRR. Words into Action: Local Disaster Risk Reduction and Resilience Strategies; UNISDR: Geneva, Switzerland, 2019; p. 59. Available online: https://www.preventionweb. net/files/57399_57399localdrrandresiliencestrategie.pdf (accessed on 23 May 2020).

17. National Authority of Civil Protection. National Evaluation of Risks. 2019. Available online: http://www.prociv.pt/bk/RISCOSPREV/AVALIACAONACIONALRISCO/PublishingImages/Paginas/ default/ANR2019-vers\%C3\%A3ofinal.pdf (accessed on 23 January 2020). (In Portuguese)

18. National Authority of Civil Protection and Emergency. General Law. 2019. Available online: http://www.prociv.pt/pt-pt/PROTECAOCIVIL/LEGISLACAONORMATIVOS/LEGISLACAOGERAL/ Paginas/default.aspx (accessed on 23 January 2020). (In Portuguese)

19. Setubal City Hall. Emergency Plan of Municipal Civil Protection, Setubal, Portugal. 2014. Available online: https://www.mun-setubal.pt/wp-content/uploads/2018/07/Plano-Municipal-de-Emerg\%C3\%AAnciae-Prote $\%$ C3\%A7\%C3\%A3o-Civil.pdf (accessed on 23 January 2020). (In Portuguese)

20. Setubal City Hall. Evacuation Plan of Setubal, Setubal, Portugal. 2012. Available online: https://www.mun-setubal.pt/wp-content/uploads/2018/07/Plano-de-Evacua\%C3\%A7\%C3\%A3o-daCidade-de-Set\%C3\%BAbal.pdf (accessed on 23 January 2020). (In Portuguese)

21. Setubal City Hall. External Emergency Plan-Mitrena Peninsula, Setubal, Portugal. 2010. Available online: https://www.mun-setubal.pt/wp-content/uploads/2018/07/Plano-de-Emerg\%C3\%AAncia-Externoda-Pen\%C3\%ADnsula-da-Mitrena.pdf (accessed on 23 January 2020). (In Portuguese)

22. Setubal City Hall. Municipal Intervention Plan in the Historic Center, Setubal, Portugal. 2010. Available online: https://www.mun-setubal.pt/wp-content/uploads/2018/07/Plano-de-Interven\%C3\%A7\%C3\%A3ono-Centro-Hist\%C3\%B3rico-de-Set\%C3\%BAbal.pdf (accessed on 23 January 2020). (In Portuguese)

23. Setubal City Hall. Municipal Forest Defense Plan against Fires, Setubal, Portugal. 2015. Available online: https://www.mun-setubal.pt/wp-content/uploads/2018/07/Plano-Municipal-de-Defesa-da-FlorestaContra-Inc\%C3\%AAndios.pdf (accessed on 23 January 2020). (In Portuguese)

24. Setubal City Hall. Municipal Plans for The Spatial Planning, Setubal, Portugal. 2019. Available online: http://www.mun-setubal.pt/diversos/pmot/plano_m.html (accessed on 23 January 2020). (In Portuguese)

25. Pluvial Drainage Plan in the Setubal County Final Report, Descriptive and Justificative Memory, Setubal municipality, Setubal, Portugal. 2011. Available online: https://www.mun-setubal.pt/wp-content/uploads/ 2020/03/DrenagemPluvialBacias-2aFase-RelatorioFinal.pdf (accessed on 23 January 2020). (In Portuguese) 
26. Zezere, J.L.; Neves, M.; Reis, E.; Fonseca, N.; Pereira, S.; Santos, A.; Lopes, A.; Correia, E. Report on Natural, Mixed and Technological Risks: Evaluation and Cartography Of Natural, Mixed and Technological Risks in the Setubal County, Setubal, Portugal. 2012. Available online: https://www.mun-setubal.pt/wp-content/ uploads/2020/03/RPDMS_A_ECTM_Riscos_DP.pdf (accessed on 23 January 2020). (In Portuguese)

27. Zezere, J.L.; Neves, M.; Reis, E.; Fonseca, N.; Pereira, S.; Santos, A. Delimitation of the National Ecological Reserve, Setubal, Portugal. 2012. Available online: https://www.mun-setubal.pt/wp-content/uploads/2020/ 03/RPDMS_Delimitacao-REN-Bruta.pdf. (accessed on 23 January 2020). (In Portuguese)

28. Setubal city Hall. Municipal Directive of Civil Protection and Firefighters-Metamorphose. Setubal, Portugal. 2013. Available online: https://www.mun-setubal.pt/protecao-civil-municipal/ (accessed on 23 January 2020). (In Portuguese)

29. Setubal City Hall. Arrabida without Cars, Setubal Beaches to Everyone, Youtube. 2019. Available online: https://www.youtube.com/watch?time_continue=68\&v=6KQgtL4yVVE\&feature=emb_logo (accessed on 23 January 2020).

30. Vicencio, H. Site Effects on Barreiro and Setúbal Counties in the Face of Seismic Risk. Ph.D. Thesis, Faculdade de Ciências e Tecnologia da Universidade Nova de Lisboa, Lisboa, Portuguese, 2017. (In Portuguese)

31. Tomé, M. Setubal: Architectonic Topology and Tipology (14th-19th Centuries), Memory and Future of the Urban Image. Ph.D. Thesis, Universiade da Beira Interior Engenharia, Coimbra, Portuguese, 2014. (In Portuguese)

32. INE. Census of Portugal 2011. Lisboa: Instituto Nacional de Estatística. 2011. Available online: http://www.ine.pt (accessed on 23 January 2020). (In Portuguese)

33. Setubal City Hall. Pilot Tsunami Alert System in Setubal. 2011. Available online: https://www.youtube.com/ watch?v=lgO2XdKZ8S4\&t=1s (accessed on 23 January 2020). (In Portuguese)

34. Euronews. Tsunami Alert-Futuris. 2014. Available online: https://www.youtube.com/watch?v= k63PY1PqVBU\&t=86s (accessed on 23 January 2020). (In Portuguese)

35. IOC. Sea Level Station Monitoring Facility. Available online: http://www.ioc-sealevelmonitoring.org/map.php (accessed on 23 January 2020).

36. Santos, A.; Tavares, A.O.; Emidio, A. Comparative tsunami vulnerability assessment of an urban area: An analysis of Setubal city, Portugal. Appl. Geogr. 2014, 55, 19-29. [CrossRef]

37. Setubal Municipality. Memory of the 28 February 1969, the Night on Which Portugal Shock. 2019. Available online: https://www.youtube.com/watch?v=xU3cSCuZiTY (accessed on 23 January 2020). (In Portuguese)

38. SIC, Big Report Program, Shacking Portugal. SIC TV Portuguese Channel, Broadcasted originally on 28 February 2019. Available online: https://sicnoticias.pt/programas/reportagemsic/2019-02-28-TremendoPortugal-esta-o-pais-preparado-para-um-grande-sismo- (accessed on 23 January 2020).

39. Flood Resilience Alliance: Flood Resilience Measurement for Communities (FRMC)_Understanding the Concepts and Principles behind the Approach; Zurich Flood Resilience Alliance (ZFRA): Zurich, Switzerland, 2019; p. 16. Available online: http://repo.floodalliance.net/jspui/bitstream/44111/3311/1/1041-PA-ZFRA-FRMCKey-Concepts-and-Principles-V5b-WEB.pdf (accessed on 23 January 2020).

40. Portuguese Council of Ministers. 2020. Available online: https://www.portugal.gov.pt/pt/gc22/governo/ comunicado-de-conselho-de-ministros?i=330 (accessed on 19 May 2020). (In Portuguese)

41. General Direction of Health (DGS). Situation Reports of COVID-19. Available online: https://covid19.minsaude.pt/relatorio-de-situacao/ (accessed on 19 May 2020). (In Portuguese)

42. General Direction of Health (DGS). Current State Point in Portugal of COVID-19. Available online: https: //covid19.min-saude.pt/ponto-de-situacao-atual-em-portugal/ (accessed on 19 May 2020). (In Portuguese)

43. Caldeira, D. Dossier COVID-19 municípios: Câmara Municipal de Setúbal. CEIPC Newsletter Inform@, 68. April 2020; 10-11.

44. Setubal City Hall. Information Related to the COVID-19. Available online: https://www.mun-setubal.pt/ covid-19/ (accessed on 19 May 2020). (In Portuguese)

45. ESRI Portugal. Evolution of COVID-19 in Portugal. Available online: https://experience.arcgis.com/ experience/8c019f41b55a41928785648ed1f82551/page/page_1/?data_id=dataSource_1-COVID_Concelhos_ ARS_View2_5966\%3A5\%2Cwidget_30-output\%3A5\&views=view_8 (accessed on 19 May 2020). (In Portuguese) 
46. Kemec, S.; Duzgun, H.S. Use of 3D Visualization in Natural Disaster Risk Assessment for Urban Areas. In Innovations in 3D Geo Information Systems, Lecture Notes in Geoinformation and Cartography; Abdul-Rahman, A., Zlatanova, S., Coors, V., Eds.; Springer: Berlin/Heidelberg, Germany, 2006; pp. 557-566.

47. Fekete, A.; Fiedrich, F. Urban Disaster Resilience and Security. In Addressing Risks in Societies; Springer International Publishing: Berlin/Heidelberg, Germany, 2018; ISBN 978-3-319-68605-9.

48. Global Alliance for Urban Crises. Urban Profiling for Better Responses to Humanitarian Crises. 2019. Available online: https://www.preventionweb.net/files/63918_1.urbanprofilingforbetterresponsest.pdf (accessed on 19 May 2020).

49. Singleton, A.D.; Longley, P.A. Geodemographics, visualisation, and social networks in applied geography. Appl. Geogr. 2009, 29, 289-298. [CrossRef]

50. Räsänen, A.; Lein, H.; Bird, D.; Setten, G. Conceptualizing community in disaster risk management. Int. J. Disaster Risk Reduct. 2020, 45, 101485. [CrossRef]

51. UN-Habitat: Urban Resilience Hub. Available online: http://urbanresiliencehub.org/ (accessed on 23 January 2020).

(C) 2020 by the authors. Licensee MDPI, Basel, Switzerland. This article is an open access article distributed under the terms and conditions of the Creative Commons Attribution (CC BY) license (http://creativecommons.org/licenses/by/4.0/). 